\title{
Funding Online Services from the Materials Budget
}

\author{
Jay Martin Poole and Gloriana St. Clair
}

\begin{abstract}
During this transitional time of decreasing library budgets and an increasing requirement for online services, it behooves librarians to consider all the possible sources for funding these new and demanded services. The information provided by an online search satisfies legitimate educational and research needs and should be funded with monies from the print materials budget. As automated information services become more prevalent, it is essential that libraries find permanent funding to support this activity.
\end{abstract}

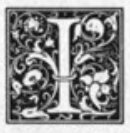

n 1981 the American Library Association produced a boldly designed and handsomely executed poster showing a stylized American flag with the words FREE underneath it. While this poster was a masterpiece of design and in fact extremely effective as a propagandistic tool, its message cannot be interpreted as anything except a well-intentioned departure from the truth. Libraries have never been, nor can they ever be, free. They are expensive to create and maintain, and, as their mission becomes increasingly tied to sophisticated automated systems, so their price escalates.

Since libraries cannot be free, the questions concern who will pay for them, how the appropriated monies will be divided, and which services will be offered from what funds. While libraries are as sacred as motherhood and apple pie to American civilization, their services are in fact targeted at a relatively small percentage of the population. In the case of academic libraries, the services are traditionally restricted to a cleanly defined population.

Libraries have always been faced with the problem of dividing their resources, and at this juncture the difficulty has been exacerbated by decreasing budgets and increasing costs of modern services and ma- terials. The availability of computerized database services for education and research has dropped a new problem into the already complex issue of how to divide a research library's budget. Libraries have responded variously. Since the expenses of an online search are easily measurable, the cost of what has been perceived as a new service has been totally passed on to the user in some cases. Some other libraries have partially underwritten the costs of the searches to various extents. In certain instances online searching has been available without charge. These monies are raided from already strained operating budgets.

\section{LITERATURE REVIEW}

The literature contains many articles on charging or not charging for online services in different environments. Fee or free seemed to dominate library literature, especially in the late 1970s. In 1977, the council and membership of the American Library Association passed a resolution asserting that the charging of a fee for information services was discriminatory. ${ }^{1}$ More recently, articles continue to appear but offer no specific information about the impact on materials budgets. Suzetta Burrows and August Lahocco, in "Fees for Automated Reference Services in Aca-

Jay Martin Poole is assistant university librarian for public services at the University of California, Irvine, California 92713. Gloriana St. Clair is associate professor and head of the Acquisitions Division, Sterling C. Evans Library, at Texas AEM University, College Station, Texas 77843. 
demic Health Science Libraries: No Free Lunches," indicate that ten years after the introduction of Medline, most institutions still charge fees. ${ }^{2}$ Carolyn G. Weaver, in "Free Online Reference and Fee-based Online Services: Allies, not Antagonists," weighs the arguments on both sides for publicly supported libraries and suggests a compromise. ${ }^{3}$

In "Free Online Searching in a Public Library System: An Unscientific Study," Georgia Fox Donati and Martha Moss Kreisel describe the implementation of free searching in the Westchester Library System in New York. ${ }^{4}$ In "Will Public Libraries be Obsolete in the 1980's," J. William Baker notes the difficulties libraries have in obtaining funds for automated retrieval equipment and the publishers' projections for decreases in book use. ${ }^{5}$ John Budd applies the U.S. code on free access to information to this problem in "The Terminal and the Terminus: The Prospect of Free Online Bibliographic Searching. ${ }^{16}$

Carlos A. Cuadra calls online retrieval an equalizer between the information haves and the information have-nots in "Commercially Funded On-line Retrieval Services-Past, Present, and Future. ${ }^{\prime 7}$ In "Online Services: Beyond Fee or Free," Sara D. Knapp addresses the question of whether three academic libraries should charge users for online searches. ${ }^{8}$ In "Free Online Searches are Feasible," Paula J. Crawford and Judith A. Thompson conclude that online services should be free for users in academic and research libraries but do not address the problem of how to fund them beyond a simple statement that "Monies allocated for searches are taken from the budget for supplies and services," to be divided among academic departments based on past demand." Mary Huston in "Fee or Free: The Effect of Charging on Information Demand" also urges alternatives to direct user fees whenever possible. ${ }^{10}$ And in "Budgeting to Provide Computer-based Reference Services: A Case Study," Sara D. Knapp and C. James Schmidt discuss costs, planning, organizational, and managerial considerations but do not indicate what part of the budget was used. ${ }^{11}$

Several authors note criteria for dividing library materials budgets. In "A Formula for Allocating Book Funds: The Search for Simplicity and Flexibility," Fabian Ehikamenor demonstrates the use of a welltested formula for dividing book funds at universities in Nigeria. ${ }^{12}$ Stephen Toney notes efficiency improvements from improved knowledge of resource allocations by tagging expenditures with goals in "A Cost Database for Branch Library Resource Allocation and Performance Evaluation." ${ }^{13}$ In "Problems and Potentials of Linking Acquisitions and Circulation Systems," Nolan Pope notes possible sources for collection development information and evaluation. ${ }^{14}$ Marcia L. Sprules in "Online Bibliometrics in an Academic Library" reports a study of journal usage isolated through computerized databases. ${ }^{15}$

And Rowland Lorimer in "Implications of the New Technologies of Information" argues that despite the inherent biases of new technologies, benefits must be shared all around. He believes that the electronic communications revolution "can exacerbate inequalities of power and concentrate knowledge in the hands of a few. ${ }^{\prime 16} \mathrm{He}$ fears that individuals, corporations, universities, and countries can partake of an unequal power base as easily as they can contribute the establishment of "a global equilibrium in creative intelligence."

\section{RESOLVED}

The information provided by an online search satisfies legitimate educational and research needs and should be funded with monies from the print materials budget. This act should not be seen as a final resolution to the problem but rather as a transition measure to be used until libraries can establish the efficacy of this expenditure, justify it to their funding agencies, and acquire permanent funding designated for this use.

Historically libraries have spent millions of dollars to buy print materials. The conjunction of selection and acquisition is that materials monies are inevitably spent, to a greater or lesser extent, on a "probable need" principle. While librarians have studied their patterns of buying with all the statistical tools known, the continuing result is that many purchases of books are 
professional hypotheses on the part of the librarian. From a penchant for statistics, librarians know that a very small percentage of the books bought serve the major portion of user needs.

Naturally some decisions to purchase are more precise than others. When a professor requests supplementary reserveroom reading materials for a large lecture course, the probablility is high that the print materials will at least have the appearance of being used.

Approval plans, which allow libraries to establish a pattern of needs, provide a more codified type of planning. The tremendous savings they offer by lowering selection and acquisition costs without apparently degrading selection quality make them attractive to institutions already under budgetary strain.

Collection development and management involve careful studies of the strengths and weaknesses of the collection as it complements the curriculum of the institution. Still, no matter how carefully constructed the procedure, the collection manager is always attempting to anticipate the needs of the user.

A collection's lack of use is rationalized by the idea that the material may be used in the future. If this future use does not materialize in the short term, the materials may be used for research purposes at some far-removed occasion. As a consequence, storage facilities are constructed to house materials of possible historical interest, and librarians agonize over their archival functions.

The knowledge and experience that librarians have brought to the process of selection has resulted in collections that fulfill user demands. However, librarians must accept the fact that many materials purchased are infrequently if ever used.

The summation of this perplexity of selection and acquisition is that the "probable need" principle dominates spending of materials monies. An element of contingency persists in collection building.

In fact, libraries have always spent large portions of their budgets on processing and analyzing materials to make them accessible. The costs of materials selection, acquisition, cataloging, and processing have always been considered essential. To collect and store the materials without analyzing their contents and providing access has never been a research library alternative. Only recently, with the advent of Robinson-style libraries, have a few public librarians accepted this as an alternative. ${ }^{17}$

Spending monies for access to materials is a traditional, in fact, essential, library practice. Large chunks of materials monies cannot be accommodated without at least equal funds for acquisitions and cataloging. ${ }^{18}$ More and more frequently, libraries have recognized the extent of these added costs and begun to request them in budget justifications and grant proposals.

Thus, access and materials are integral to the user's relationship to the library. The relative amounts of money spent on them, while technically divided in the library's budget, are not separable. Monies taken from the service budget impact on the amount available for the materials budget. The natural outgrowth of the realization that comparable amounts of money must be spent on access leads to an acceptance of online access as an interim materials expenditure.

The access provided by online searching is as legitimate a use of funds as that provided by the processing of materials. Indeed the precise and careful construction of online searching is an efficient use of funds for providing access. "When we do an online search, it is tailor-made for someone. . . . It is not like a book, which we buy for everyone to use," says Suzanne H. Gallup in "Computerized DataBase Services for Research Bring Era of 'Free' Library Service to End." ${ }^{\prime 19}$ Since the search is precisely defined, the probability of its being used is insured. Consequently, the tailor-made use of the funds provides users with the beginnings of a solution to their research problems. Further, libraries have always bought books and serials for one faculty member or student to use, even though these items were inevitably added to the collection.

Funding the online search from the materials budget should proceed in a rather inevitable fashion. First, only a few journals and newsletters are now published in online format. The library should perceive this as a natural expenditure of its materi- 
als budget, for in fact, no alternative will be available. Also, data services, such as I.P. Sharpe Associates' numeric databases and Develop (Control Data Corporation), have already begun this trend. No administration, internal or external, could question this use of funds.

The next legitimate step would be to provide monies for online indexing and abstracting services that are also published in paper format. This step would require careful control of public relations propaganda and would necessitate monitoring of downtime, dirty data, and other substantive issues. After suitable periods of adjustment, the paper indexes will be foregone in favor of expenditures for their online alternatives. As technologies evolve, citations and abstracts should be supplemented by full text. Libraries should be given downloading options, either for the entire full-text contents or for only those particular items requested by patrons. The earlier selection choice is now more certain, for the user's need is expressed before it is met. Future needs will be consigned to large repositories, probably divided among concerned libraries.

While the first movers in this area may be large, specialized, highly scientific and technical publishers, more ephemeral materials such as corporate newsletters and in-house "rags" may cease to appear in paper format. The growing ubiquity of this online trend will make it easier for libraries to justify their use of materials monies to support online searching.

\section{IMPLICATIONS}

The implications of funding online searches from the materials budget are not trivial. Cost containment would be essential. Scheduling changes and library networking could be considered to reduce telecommunications and other costs. Fiber optics and satellites may afford some relief from rising telephone expenditures.

An intriguing switch on traditional philosophy might invite some courageous library to experiment with providing nocharge searches and charging for the use of the books and journals. Flat user fees or library fees, like laboratory fees, might also be ventured.
Libraries should aim for total funding. However, it might be necessary to set a limit on what percentage of a materials budget would be allocated for online searching and to determine how the services might be most equitably distributed among the library's users. For instance, nighttime use of inexpensive databases might be made available for all; slightly more sophisticated searching might be funded for graduate students and faculty (with stated limitations). In an address to the Acquisitions Roundtable of the Texas Library Association, Glyn Evans mentioned that he finds a maximum 10 percent rule of thumb useful for the State University of New York systems. ${ }^{20}$

Depending on the size of the library and the nature of the research problem, the users may then proceed to finish their research within their own library or they may be guided into the use of interlibrary loan services to meet their now established needs.

Thus, the library must plan for an increase in its interlibrary loan traffic because of the breadth and sophistication of the data retrieved. Staffing must be adequate and the fee monies available.

The balance among the disciplines in the university's curriculum must also be guarded. Because industry uses them, scientific, technological, and business databases tend to be more highly priced than those in the humanities and arts. The library should mediate to maintain balance, but each involved department should also be aggressive on its own behalf. Everybody in social sciences, humanities, and arts must press for the use of databases and must become familiar with the advantages of the technologies involved.

One other caution seems necessary. J. Bronowski says in The Ascent of Man:

Johnny Von Neumann was in love with the aristocracy of intellect. And that is a belief which can only destroy the civilization that we know. If we are anything, we must be a democracy of the intellect. We must not perish by the distance between people and government, between people and the power, by which Babylon and Egypt and Rome failed. And that distance can only be conflated, can be closed, if knowledge sits in the homes and heads of people with no ambition to control others, and not up in the isolated seats of power. ${ }^{21}$ 
Echoed by many concerned citizens, Bronowski compels librarians to provide equal and effective access to all regardless of the source of funding.

Funding of online searching from the materials budget should be offered as an interim measure. If funded searching succeeds in increasing user satisfaction, the case must be made for separate permanent funding in the future.
In the long range, budgets need to be supplemented to provide for the kind of superior library service now available. Using the materials budget in the interim should allow a library time to gather sufficient data and to gain significant faculty and student support. Then, administrators should be prepared to go to suitable sources and return with adequate funding.

\section{REFERENCES AND NOTES}

1. Resolution on 'Free Access to Information'-Passed by ALA Membership and Council, June 1977, Detroit," Messages from MARS 6 (Sept. 1977).

2. Suzetta Burrows and August Lahocco, "Fees for Automated Reference Services in Academic Health Science Libraries: No Free Lunches," Medical Reference Services Quarterly 2:1-15 (Summer 1983).

3. Carolyn G. Weaver, "Free Online Reference and Fee-based Online Services: Allies, not Antagonists," Reference Librarian 5/6:111-18 (Fall/Winter 1982).

4. Georgia Fox Donati and Martha Moss Kreisel, "Free Online Searching in a Public Library System: An Unscientific Study," Online 7:12-19 (Mar. 1983).

5. J. William Baker, "Will Public Libraries be Obsolete in the 1980 's?" Canadian Library Journal 36:262-66 (Oct. 1979).

6. John Budd, "The Terminal and the Terminus: The Prospect of Free Online Bibliographic Searching," Research Quarterly 21:373-78 (Summer 1982).

7. Carlos A. Cuadra, "Commercially Funded On-line Retrieval Services-Past, Present, and Future," Aslib Proceedings 30:2-15 (Jan. 1978).

8. Sara D. Knapp, “Online Services: Beyond Fee or Free," Research Quarterly 20:17-20 (Winter 1980).

9. Paula J. Crawford and Judith A. Thompson, "Free Online Searches are Feasible," Library Journal 104:793-95 (Apr. 1, 1979).

10. Mary Huston, "Fee or Free: The Effect of Charging on Information Demand," Library Journal 104:1811-14 (Sept. 15, 1979).

11. Sara D. Knapp and C. James Schmidt, "Budgeting to Provide Computer-based Reference Services: A Case Study," Journal of Academic Librarianship 5:9-13 (Mar. 1979).

12. Fabian A. Ehikamenor, "A Formula for Allocating Book Funds: The Search for Simplicity and Flexibility," Libri 33:148-61 (June 1983).

13. Stephen Toney, "A Cost Database for Branch Library Resource Allocation and Performance Evaluation," College \& Research Libraries 42:373-78 (July 1981).

14. Nolan F. Pope, "Problems and Potentials of Linking Acquisitions and Circulation Systems," Library Acquisitions: Practice and Theory 4:5-11 (1980).

15. Marcia L. Sprules, "Online Bibliometrics in an Academic Library," Online 7:25-34 (Jan. 1983).

16. Rowland Lorimer, "Implications of the New Technologies of Information," Scholarly Publishing 16:197-210 (Apr. 1985).

17. Murray C. Bob, "The Case for Quality Book Selection," Library Journal 107:1707-10 (Sept. 15, 1982).

18. "Notes on . . . Libraries," The Chronicle of Higher Education 30:3 (Mar. 13, 1985). Latest research estimates indicate that the cost of acquiring and cataloging a book runs from an average of $\$ 25.52$ to $\$ 66.42$ at eight university libraries. The Bowker Annual shows average cost of a hardcover book at $\$ 30.84$ for the year 1983. The Bowker Annual of Library \& Book Trade Information, 29th ed. (New York: Bowker, 1984), p.415.

19. Judith Axler Turner, "Computerized Data-Base Services for Research Bringing Era of 'Free' Library Service to End," The Chronicle of Higher Education 29:25 (Sept. 19, 1984).

20. Glyn T. Evans, "Collection Management Information Systems," Acquisitions Round Table of Texas Library Association, Apr. 15, 1985.

21. Jacob Bronowski, The Ascent of Man (Boston: Little, 1973), p.435. 